удК:618.145-006.03-02:575.1

\author{
MALANCHUK L., MARTYNIUK V., MALANCHYN I., KUCHMA Z., KRYVYTSKA G. \\ The State Institution of Higher Education \\ «Ivan Horbachevsky Ternopil State Medical University Ministry of Health of Ukraine» \\ department of obstetrics and gynecology № 1, Ternopil
}

\title{
POLYMORPHISM GENES OF DETOXIFICATION SYSTEM AND IMMUNEDEPENDENT MECHANISMS IN THE DEVELOPMENT OF GENITAL ENDOMETRIOSIS
}

\begin{abstract}
Endometriosis is one of the most mysterious and unresolved problem in modern gynecology, taking the third place in the structure of gynecological diseases. In the genesis of endometriosis important role belongs to the metabolism genes, which are characterized by a large variability of molecular structure of DNA. It is proved that implantation of endometrial cells and their proliferation is provided, if a woman abuses humoral and cellular immunity. The aim of our study was to determine the role of polymorphisms genes of detoxification system and immunedependent mechanisms in the development of endometriosis. Material and methods. Surveyed 102 patients with internal genital endometriosis. The polymerase chain reaction investigated the frequency of polymorphic variants of genes GSTT1 and GSTM1. DNA extraction from peripheral blood was perfomed using the test system "AmpliSens». Determination of interleukins levels in serum was perfomed by the method monoparentale analysis using the test-systems for IFA. Results of the study and their discussion. The results of the conducted researches have allowed to establish that genital endometriosis is significantly associated with deleting polymorphisms genes of detoxication system. Also, it was found that patients with internal endometriosis there is a hyperproduction of proinflammatory cytokines and tumor necrosis factor- $\alpha$.
\end{abstract}

Conclusions. Research factors of immune regulation, and gene deletions of the glutation-S-transferase is a promising for future research in terms of studying them as a potential marker for noninvasive diagnosis of endometriosis.

Key words: genital endometriosis, inflammatory interleukins, and genes GSTT1, GSTM1.

The environmental crisis that swept the world in recent decades, humanity has to address, perhaps, the most complex of medical, social and economic problem - the rampant growth of the pathology of the reproductive system. Endometriosis is a mysterious gynecological disease has a multifactorial etiology and is a 10-15\% of women of reproductive age [1]. Given that in the current socio-economic conditions increased the percentage of woman for whom remains relevant reproductive function at the age of over 40 years, which encourages further study of the etiology and pathogenesis of endometriosis, which is a growing problem in Ukraine both in scientific and in practical terms. It is known that in the genesis of genital endometriosis (GE) an important role plays metabolism genes, which are characterized by a large variability of molecular structure of DNA [2,3]. The enzyme family of glutathione-S-transferases (GST) play a key role in sustaining the resilience of cells to lipid peroxidation, free radicals, alkylation of proteins, in the development of resistance to drugs and the prevention of DNA damage [4]. For all pathological processes in the human body occurs due to immunological regulation and is characterized by a certain ratio of pro- or anti-inflammatory cytokines. Based on the literature data characterizing the pathogenetic features of the development of endometriosis, it can be assumed that the occurrence of pathology in the same layer of the uterus may occur in some cases through the mechanisms dysregulation of cellular metabolism $[5,6]$. To date, the nature of the humoral regulation of immune reactions is well studied. The main endogenous immunomodulators, which take an active part in proliferative processes of the uterus and is especially active in endometriosis is interleukin-6 (IL-6), interleukin-8 (IL-8) and tumor necrosis factor alpha $(\mathrm{TNF}-\alpha)[7,8]$. 
THE AIM OF THE STUDY - to determine the role of polymorphisms genes of detoxification system and immunedependent mechanisms in the development of endometriosis.

\section{MATERIALS AND METHODS}

The clinical part of the work was carried out on the basis of Ternopil regional clinical perinatal center «Mother and child». The laboratory diagnostics was carried in interdepartmental scientific clinical laboratory of «Ternopil State Medical University Ministry of Health of Ukraine». The study included 102 patients with genital endometriosis, aged from 27 to 45 years. The bioethics commission of The State Institution of Higher Education «Ivan Horbachevsky Ternopil State Medical University Ministry of Health of Ukraine» not found violations of ethical norms in research. All patients had written informed consent was obtained for venous blood and use it for scientific work. For medical genetic research 3-5 $\mathrm{ml}$ of venous blood was taken from v. cubitalis under standard conditions in the morning, fasting in a special vacuum system - $3 \%$ EDTA. The polymerase chain reaction and investigated the frequency of polymorphic variants of genes GSTT1 and GSTM1. DNA extraction from peripheral blood was performed using the test system "AmpliSens» according to the instructions, which are attached. Identification deletion polymorphism in the genes GSTT1 and GSTM1 (glutathione-S-class trans- ferases T1 and M1) was performed by PCR, LPB «NEOGEN», Kyiv. Studies of the concentration of serum proinflammatory cytokines (IL-6, IL-8 and TNF- $\alpha$ ) were conducted on monoparentale striptime analyzer STATFAX 303 PLUS (USA) using kits of resgents

for ELISA: IL-6 and IL-8, made a joint stock company, ZAO «Vector-BEST» and the test-system for the quantitative determination of tumor necrosis factor- $\alpha$, developed by the company «Ukrmeddon" (Ukraine) with International certificate ISOS 001 IISO 13485.

\section{RESULTS OF THE STUDY AND THEIR DISCUSSION}

Thus with the aim of identifying biomarkers of predisposition to endometriosis, we have performed genetic studies. Homozygotes and heterozygotes for allele «+» genes GSTT1 and GSTM1 were determined on gel for the presence ofamplification products of size 218 p.a. (GSTM1) and the fragment of 460 p.a. (GSTT1). The lack of appropriate fragments indicated homozygotes individual for deletions of two genes. Thus, we revealed that 65 $(63,7 \%)$ women with internal genital endometriosis notes telecine carriage with two types of genes (GSTT1 and GSTM1), in $10(9,8 \%)$ by type of ins/ del and in $27(26,5 \%)$ individuals were not observed polymorphism II detoxification system (table 1).

Table 1

Distribution of GSTT1 and GSTM1 genotypes in the observed group

\begin{tabular}{|c|c|}
\hline $\begin{array}{c}\text { Observed group } \\
n=102\end{array}$ & Genotypes in the observed group \\
\hline $65(63,7 \%)$ & del/del \\
\hline $10(9,8 \%)$ & ins/del \\
\hline $27(26,5 \%)$ & the lack of polymorphism \\
\hline
\end{tabular}

After determining the levels of cytokines in the blood we are diagnosed that cytokine imbalance in women with internal genital endometriosis is characterized by shifts in the form of a hyperproduction of proinflammatory cytokines, such as IL-6, IL-8 and TNF- $\alpha$ (table 2).

Table 2

Immune system indicators in the observed group and clinical norm

\begin{tabular}{|c|c|c|}
\hline Indicator & $\begin{array}{c}\text { Observed group } \\
\mathrm{n}=102\end{array}$ & Normal levels \\
\hline $\mathrm{IL}-6(\mathrm{pg} / \mathrm{ml})$ & $21,05 \pm 0,06$ & $>10(\mathrm{pg} / \mathrm{ml})$ \\
\hline $\mathrm{IL}-8(\mathrm{pg} / \mathrm{ml})$ & $168,24 \pm 1,4$ & $>30(\mathrm{pg} / \mathrm{ml})$ \\
\hline TNF-a $(\mathrm{pg} / \mathrm{ml})$ & $7,55 \pm 0,03$ & $>5(\mathrm{pg} / \mathrm{ml})$ \\
\hline
\end{tabular}


In determining the immune status in the studied groups of patients, we found that in the group of patients with genital endometriosis the levels of interleukin-6 2.0 times significantly higher in comparison with the norm of laboratory parameters. These data evidence in favor of locality action of interleukin-6. With this increase crosses an adequate inflammatory and immune process.

In the study of interleukin-8, it was found that its concentration in serum is almost 7 times higher in comparison with indicators of norm set by the laboratory. These results may indicate marked involvement of cells of nonspecific resistance in the implementation of the inflammation in genital endometriosis.

In the observed group was an increase of TNF- $\alpha$ 1,5 times, which is a favorable prognostic sign for inflammation. It is known that tumor necrosis factor has a broad spectrum of regulatory activity and a pronounced pleiotropic effect. Also, TNF- $\alpha$ significantly affects the differentiation, proliferation and activation of cells in the site of inflammation. A significant increase of its concentration in serum is associated with disfunction of internal organs and possible conditions.

\section{CONCLUSIONS}

The clinical inquiry establishes that endometriosis is significantly associated with null genotype for the two genes with the second phase of detoxification system (GSTT1 and GSTM1) that will be important for the development of new methods of treatment and prevention, taking into account individual features of the genome. Women with genital endometriosis noted a moderate increase in the level of TNF- $\alpha$ and interleukin- 6 in blood serum that suggest an adequate regulation of the immune response during inflammatory process. Since the primary function of interleukin- 8 is to attract neutrophils to the site of inflammation, the high concentration indicates a significant activation of nonspecific resistance of the organism.

Therefore, the study of the factors of immune regulation, and gene deletions of the glutation-S-transferases is promising for further research in the aspect of studing them as a potential marker for noninvasive diagnosis of endometriosis.

\section{REFERENCES}

1. Adenomyosis: epidemiological factors / P. Vercellini, P. Vigano, E. Somigliana // Best Practical Results Clinical Gynecology. - 2006, - Vol.20 (4) - p.465-477.
2. Baranova N. Glutation-S-transferase M1 gene polymorphism and susceptibility to endometriosis in a French population / N. Baranova, R. Bothorishvilli, M. Canis // Mol. Hum. Reprod.- 2007, - Vol.3, J/b 9. - p. 775780 .

3. Ertunc D. Glutation-S-transferase genes polymorphism and susceptibility to endometriosis / D. Ertunc, M. Aban, L. Tamer, M. Arslan, S. Dilek // Mol. Hum. Reprod. 2008, - Vol.4. - p. 265-282.

4. Guo S. Epigenetics of endometriosis / S. Guo // Mol. Hum. Reprod. - 2009, - Vol. 15 (10). - p. 587-607.

5. Haider S. Human tumor necrosis factor: physiological and pathological roles in endometrium / S. Haider // Reprod. Immunol. - 2011, - Vol. 30. - p. 111-123.

6. Possible mechanism of autoimmune-mediated infertility in women with endometriosis / J. Inagaki, L. Hao, M. Nakatsuka [at al.] // Reprod. Immunol. - 2011, - Vol. 66 (2). - p. 90-99.

7. Berkkanoglu M. Immunology and endometriosis / M. Berkkanoglu, A. Arici // Am J. Reprod. Immunol. - 2003, - Vol. 50. - p. 48-59.

8. Siristatidis C. Immunological factors in the genesis and development of endometriosis / C. Siristatidis, C. Nissotakis, C. Chrelias // Obstetrics and Gynecological Res. - 2006, Vol. 32 (2). - p. 62-70.

\section{PEЗЮME}

\section{ПОЛІМОРФІЗМ ГЕНІВ СИСТЕМИ ДЕТОКСИКАЦІї ТА ІМУНОЗАЛЕЖНІ МЕХАНІЗМИ У РОЗВИТКУ ГЕНІТАЛЬНОГО ЕНДОМЕТРІОЗУ}

\author{
МАЛАНЧУК Л.М., МАРТИНЮК В.М., \\ МАЛАНЧИН І.М., КУЧМА 3.М., \\ КРИВИЦЬКА Г.О.
}

Посідаючи третє місце в структурі гінекологічної захворюваності, ендометріоз продовжує залишатися актуальною проблемою для науковців та практичних лікарів. На сьогоднішній день доведено, що в генезі генітального ендометріозу важлива роль належать генам метаболізму, які характеризуються великою варіабельністю молекулярної структури ДНК. Існують дані про підвищення локальної та системної активності при ендометріозі, що супроводжується зростанням прозапальних цитокінів та фактора некрозу пухлин альфа, які є промоторами неоангіогенезу, обов'язкового компонента формування та розвит- 
ку ендометріоїдних гетеротопій. Метою нашого дослідження було визначити роль поліморфізму генів системи детоксикації та імунозалежних механізмів у розвитку генітального ендометріозу. Матеріали і методи. Нами обстежено 102 пацієнтки репродуктивного віку із генітальним ендометріозом. Для проведення медико-генетичних досліджень відбиралось 3-5 мл венозної крові, яку брали із v.cubitalis в стандартних умовах. Ампліфікацію геномних послідовностей проводили за допомогою полімеразної ланцюгової реакції на ампліфікаторі «PCR-System 2400» із застосуванням набору реагентів фірми «AmpliSens-100R». Дослідження концентрації в сироватці крові прозапальних цитокінів проводилось на імуноферментному стріптовому аналізаторі STATFAX 303 PLUS (USA) за допомогою наборів для реактивів для ІФА. Результати дослідження та їх обговорення. Результати проведених досліджень дозволили встановити, що генітальний ендометріоз асоціюється із делеційним поліморфізмом генів GSTT1 та GSTM1. Також було встановлено, що у жінок із внутрішнім генітальним ендометріозом спостерігається достовірне $(\mathrm{p} \leq 0,05)$ підвищення концентрації в сироватці крові прозапальних цитокінів та ФНП- $\alpha$.

Висновки. Вивчення факторів імунної регуляції та генних поліморфізмів II фази системи детоксикації $\mathrm{e}$ перспективним для подальших наукових досліджень в аспекті використання їх як можливих маркерів неінвазивної діагностики генітального ендометріозу.

Ключові слова: генітальний ендометріоз, прозапальні інтерлейкіни, гени GSTT1 та GSTM1.

\section{PEЗЮME}

\section{ПОЛИМОРФИЗМ ГЕНОВ СИСТЕМЫ ДЕТОКСИКАЦИИ И ИММУНОЗАВИСИМЫ МЕХАНИЗМЫ В РАЗВИТИИ ГЕНИТАЛЬНОГО ЭНДОМЕТРИОЗА}

\author{
МАЛАНЧУК Л.М., МАРТЫНЮК В.Н., \\ МАЛАНЧИН И.Н., КУЧМА З.Н., \\ КРИВИЦКАЯ Г.О.
}

Занимая третье место в структуре гинекологической заболеваемости, эндометриоз продолжает оставаться актуальной проблемой для ученых и практических врачей. На сегодняшний день доказано, что в генезисе генитального эндометриоза важна роль принадлежит генам метаболизма, которые характеризуются большой вариабельностью молекулярной структуры ДНК. Существуют данные о повышении локальной и системной активности при эндометриозе, что сопровождается ростом провоспалительных цитокинов и фактора некроза опухолей альфа, которые являются промоторами неоангиогенеза, обязательного компонента формирования и развития эндометриоидных гетеротопии. Целью нашего исследования было определить роль полиморфизма генов системы детоксикации и иммунозависимых механизмов в развитии генитального эндометриоза. Материалы и методы. Нами обследовано 102 пациентки репродуктивного возраста с генитальным эндометриозом. Для проведения медико-генетических исследований отбиралось 3-5 мл венозной крови, которую брали c v.cubitalis в стандартных условиях. Амплификации геномных последовательностей проводили с помощью полимеразной цепной реакции на амплификатоpe «PCR-System 2400» с применением набора реагентов фирмы «AmpliSens-100R». Исследование концентрации в сыворотке крови провоспалительных цитокинов проводилось на иммуноферментном стриптовом анализаторе STATFAX 303 PLUS (USA) с помощью наборов для реактивов для ИФА. Результаты исследования и их обсуждение. Результаты проведенных исследований позволили установить, что генитальный эндометриоз ассоциируется с делецийным полиморфизмом генов GSTT1 и GSTM1. Также было установлено, что у женщин с внутренним генитальным эндометриозом наблюдается достоверное ( $\mathrm{p} \leq$ 0,05) повышение концентрации в сыворотке крови провоспалительных цитокинов и ФНО- $\alpha$. Выводы. Изучение факторов иммунной регуляции и генных полиморфизмов II фазы системы детоксикации является перспективным для дальнейших научных исследований в аспекте использования их в качестве возможных маркеров неинвазивной диагностики генитального эндометриоза.

Ключевые слова: генитальный эндометриоз, провоспалительные интерлейкины, гены GSTT1 и GSTM1. 